\title{
Analysis of the Core Competency of Small and Medium-Sized Commercial Banks in China
}

\author{
Lu Guan \\ School of Statistics and Mathematics \\ Inner Mongolia Finance and Economics University \\ Hohhot 010070, China \\ guanlusxy@126.com
}

\begin{abstract}
Through analyzing the current development of China's small and medium-sized commercial banks, this article discusses problems such as the imperfect management system of small and medium-sized enterprises during core competency construction, the lack of knowledge accumulation and product service innovation, short-sighted strategic vision of small and medium-sized commercial banks, and lack of centralization of advantageous resources. The article suggests that China's small and medium-sized commercial banks should construct core competency via constructing core values conforming to characteristics of the bank, obtain product innovation capabilities, cultivate capabilities of the bank administrative staff, and strengthen human resource management within the bank. The investigation discussed in this article holds practical significance in promoting the development of China's small and medium-sized commercial banks.
\end{abstract}

Keywords-Small and medium-sized commercial banks; core competency; Construct; innovation

\section{THE CONCEPT AND TYPES OF CHINESE SMALL AND MEDIUM- SIZED COMMERCIAL BANKS}

According to the current situation of large Chinese banks, the ownership and right of management are controlled by the government, and has in a long time monopolized properties. In recent years, although the market share of small and mediumsized commercial banks has gradually increased, the total assets of large banks still counts up to over $50 \%$ of total assets of financial institutions. Therefore the objective conditions that classify small and medium-sized commercial banks such as asset size and market pattern do not include the five stateowned commercial banks. Hence the small and medium-sized commercial banks discussed in this article refer to the twelve medium-sized joint-equity commercial banks, city commercial banks and rural financial institutions such as rural credit cooperatives [1].

\section{A. City commercial bank}

In the 1980's of the past century, China's city commercial banks have begun to rise mainly through urban credit cooperatives built from individually-owned businesses and collective economy. Beginning from 1995 the government has gradually recalled urban credit cooperatives, and at the same time organized in many cities two local city stock cooperative banks, forming its share through local finance and resident investment. Since the first city commercial bank in China, the Shenzhen city cooperative bank, came to being in 1995, Chinese commercial banks have gone through unstoppable rapid development. As shown in Fig. 1, the total asset of Chinese city commercial banks in 2015 amounts to 22.68 trillion yuan, which is $11 \%$ of the banking industry. With the commercial banks' continuous increase of market share and the decrease of non-performing loans, Chinese city commercial banks frequently appear in the first 500 ranking of world's banking industries. Shown in Table I, according to the various evaluation standards, the Bank of Beijing is top among city commercial banks in 2015.

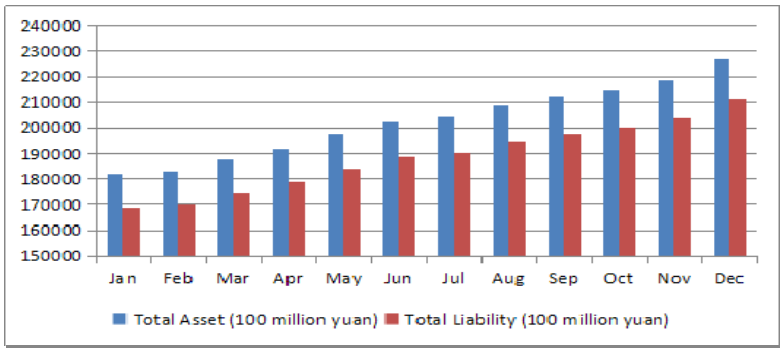

Fig. 1. Asset and liability of city commercial banks in 2015 Data source: Official website of the China Banking Regulatory Commission

TABLE I. TOP 10 CITY COMMERCIAL BANKS IN CHINA AS OF 2015 UNIT: SCORE

\begin{tabular}{|c|c|c|c|c|c|}
\hline & $\begin{array}{c}\text { Bank of } \\
\text { Beijing }\end{array}$ & $\begin{array}{c}\text { Bank of } \\
\text { Jiangsu }\end{array}$ & $\begin{array}{c}\text { Bank of } \\
\text { Shanghai }\end{array}$ & $\begin{array}{c}\text { Bank of } \\
\text { Nanjing }\end{array}$ & $\begin{array}{c}\text { Bank of } \\
\text { Ningbo }\end{array}$ \\
\hline iBrand & 82.46 & 81.65 & 81.91 & 81.76 & 81.89 \\
\hline iSite & 97.85 & 86.62 & 81.04 & 87.99 & 85.14 \\
\hline iPower & 91.52 & 91.04 & 91.19 & 85.73 & 85.54 \\
\hline Total score & 91.39 & 90.35 & 90.22 & 85.86 & 85.34 \\
\hline & $\begin{array}{c}\text { Huishang } \\
\text { Bank }\end{array}$ & $\begin{array}{c}\text { Shengjing } \\
\text { Bank }\end{array}$ & $\begin{array}{c}\text { Hangzhou } \\
\text { Bank }\end{array}$ & $\begin{array}{c}\text { Baoshang } \\
\text { Bank }\end{array}$ & $\begin{array}{c}\text { Bank of } \\
\text { Tianjin }\end{array}$ \\
\hline iBrand & 82.80 & 75.89 & 83.25 & 81.36 & 78.08 \\
\hline iSite & 85.28 & 75.66 & 82.10 & 95.43 & 64.00 \\
\hline iPower & 84.83 & 85.03 & 84.19 & 83.03 & 84.79 \\
\hline Total score & 84.71 & 84.11 & 84.03 & 83.57 & 83.41 \\
\hline \multicolumn{5}{|c|}{ Data source: China Internet Weekly, 2015, Volume 21 }
\end{tabular}

\section{B. Rural Credit Cooperatives}

After twenty years of transformation of rural credit cooperatives in China, the effects have shown to be outstanding, and the non-substitutable role is particularly evident in the rural financial market. According to recent statistics, rural credit cooperatives have completed more than half of the rural deposit and more than 7/10 rural loans and loans of township enterprise. As shown in Fig. 2, in December 2015, the 
percentage of total assets and total liabilities of rural financial institutions out of all financial institutions of the banking industry increases year after year, the proportion being $13.2 \%$ and $13.3 \%$. In their rapid development, the general development status of rural credit cooperatives still presents many problems; for instance, loan sizes are relatively small, there are deficits in the operations, the rate of non-performing loans is high, and the capital adequacy ratio is low.

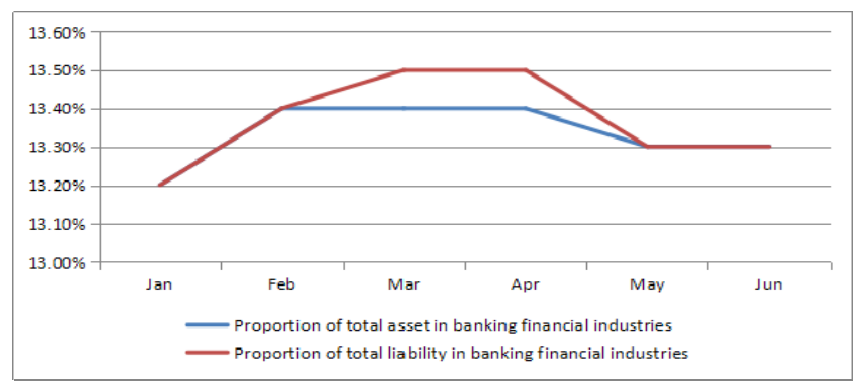

Fig. 2. Proportions of the total asset and total liability of rural financial industries among banking financial industries

Data source: Official website of the China Banking Regulatory Commission

After twenty years of transformation of rural credit cooperatives in China, the effects have shown to be outstanding, and the non-substitutable role is particularly evident in the rural financial market. According to recent statistics, rural credit cooperatives have completed more than half of the rural deposit and more than 7/10 rural loans and loans of township enterprise. As shown in Figure 2, in December 2015, the percentage of total assets and total liabilities of rural financial institutions out of all financial institutions of the banking industry increases year after year, the proportion being $13.2 \%$ and $13.3 \%$. In their rapid development, the general development status of rural credit cooperatives still presents many problems; for instance, loan sizes are relatively small, there are deficits in the operations, the rate of non-performing loans is high, and the capital adequacy ratio is low.

\section{Joint-equity Commercial Banks}

Due to the rising and fast development of China's joint equity commercial banks, currently there are 12 medium sized joint equity commercial banks in China. Up until December 2015, the total asset has risen $17.7 \%$ compared with the same period last year, and total liability has risen $17.5 \%$. Joint equity commercial banks are created according to the organization system of modern enterprises; they have specialties such as flexible operations and clear responsibility and authority, which benefit the rapid development of joint equity banks, improve the financial market and prompts rapid economic development.

\section{CurRent DEVElopment Status of ChInA'S SMALl AND MEDIUM-SIZED COMMERCIAL BANKS}

Table II shows the various statistics of commercial banks' market capacity in 2014; the overall cumulative net profit has increased 249.575 billion yuan more than the previous year and the growth rate has reached $9.65 \%$. On the other hand, the average capital profit and the average return on assets have equally decreased. Net profit has slowed down in growth rate and credit risk index continues to rise. By the end of the year, the number of non-performing loans still grows continuously, increasing $0.25 \%$ and amounting up to 250.6 billion yuan compared with statistics in the beginning of the year. Data shows that the loan loss provision is 281.2 billion yuan more than the beginning of the year and the capital adequacy ratio is still relatively high; this means that the bank has a fairly strong anti-risk ability. Simultaneously, the weighted average tier-one capital adequacy ratio and the weighted average capital adequacy ratio are both higher than the statistics of January 2014. The $2.42 \%$ increase in liquidity ratio compared with statistics of January 2014 reveals the strengthening of liquidity; and the $2.42 \%$ increase in RMB excess reserve rate shows the efficient use of funds.

TABLE II. COMMERCIAL BANK MARKET CAPACITY IN 2014 UNIT: 100 MILLION YUAN, \%

\begin{tabular}{|c|c|}
\hline Overall cumulative net profit & 15500 \\
\hline Balance of non-performing loans & 8426 \\
\hline Rate of non-performing loans & 1.25 \\
\hline Balance of loan loss provision & 19600 \\
\hline $\begin{array}{c}\text { Weighted average core tier-one capital adequacy } \\
\text { ratio }\end{array}$ & 10.56 \\
\hline Weighted average tier-one capital adequacy ratio & 10.76 \\
\hline Weighted average capital adequacy ratio & 13.18 \\
\hline Liquidity ratio & 46.44 \\
\hline RMB excess reserve rate & 2.65 \\
\hline Data source: Market survey and future prospects report of China's small and medium-sized \\
commercial banks in 2016
\end{tabular}

TABLE III. CAPITAL LIABILITY STATUS OF VARIOUS CHINESE COMMERCIAL BANKS IN 2014 UNIT: TRILLION YUAN, \%

\begin{tabular}{|c|c|c|c|}
\hline & Total assets & $\begin{array}{c}\text { Total } \\
\text { liabilities }\end{array}$ & Debt asset ratio \\
\hline $\begin{array}{c}\text { Industrial and Commercial Bank } \\
\text { of China (ICBC) }\end{array}$ & 20.6 & 19.1 & 92.54 \\
\hline $\begin{array}{c}\text { Agricultural Bank of China } \\
\text { (ABC) }\end{array}$ & 16.0 & 14.9 & 93.54 \\
\hline Bank of China (BOC) & 15.3 & 14.1 & 92.24 \\
\hline $\begin{array}{c}\text { Shanghai Pudong Development } \\
\text { Bank (SPD Bank) }\end{array}$ & 4.20 & 3.93 & 93.73 \\
\hline China CITIC Bank & 4.14 & 3.87 & 93.54 \\
\hline \multicolumn{3}{|c|}{ Data source: China Finance Net }
\end{tabular}

Table III reveals that the debt asset ratio of joint-equity commercial banks are higher than state-owned commercial banks; according to this perspective, the asset amount of small and medium-sized commercial banks are far fewer than stateowned commercial banks, therefore small and medium-sized commercial banks are more affected by cash flow, and are more vulnerable to systemic financial risks. However, small and medium-sized commercial banks have many competitive advantages: their share of the market is not large, and have more small and medium-sized client groups in terms of customer resources; under the situation of which foreign banks are advancing towards the Chinese banking industry, small and medium-sized commercial banks are not affected as much as others; their business strategy and marketing techniques are more flexible and their outstanding management structure is also evident. 


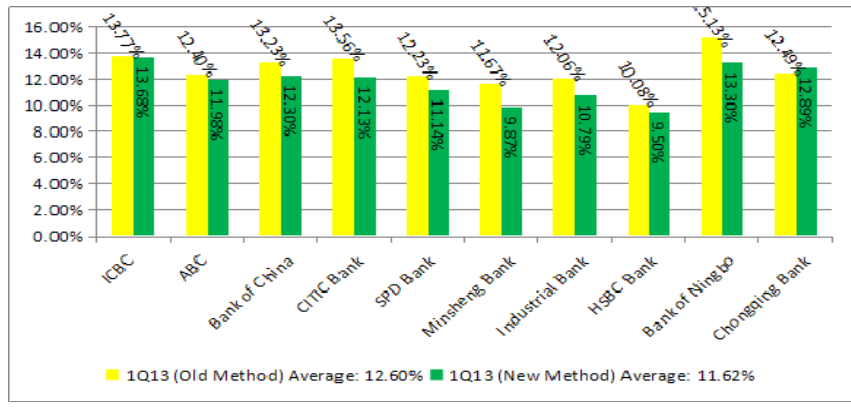

Fig. 3. A comparison of the capital adequacy ratio of various commercial banks in 2014

Data source: China Finance Net

Fig. 3 shows that Chinese small and medium-sized commercial banks have relatively low capital adequacy ratios compared to large state-owned banks. Small and medium-sized commercial banks are rather sensitive to liquidity; once the inter-bank offered rate undergoes large fluctuations, small and medium-sized commercial banks would have a relatively hard time coping with it. Also, in the statistics given above, banks with lower capital adequacy ratios such as the HSBC bank and the Minsheng bank are in urgent need of capital replenishment. In order to enrich and improve the capital adequacy ratio of banks, a majority of China's listed banks adopt methods such as capital injection to strip off non-performing assets; therefore they have not truly met the listing requirements, and their actual capital adequacy ratios are, generally, still lower than foreign banks.

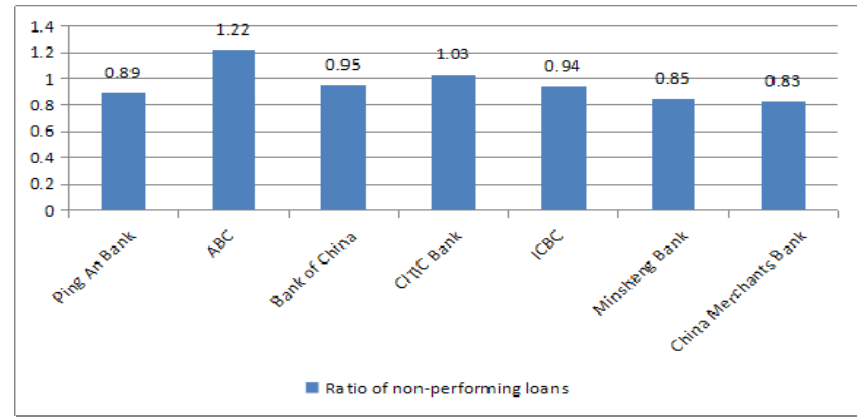

Fig. 4. Ratio of non-performing loans of various commercial banks in 2014 Data source: China Finance Net

Seeing from the statistics on Fig. 4, although the ratio of non-performing loans of joint-equity commercial banks are slightly lower than large state-owned commercial banks, their rising rates are relatively fast; such a trend is not optimal with regards to the development of these banks. Currently, there are still loopholes within the ratio of non-performing loans of small and medium-sized commercial banks, and this issue have caused a relatively high exhaustion of bank capital, worsening the banks' capital structures and restraining the advancement of China's small and medium-sized banks.

\section{PROBLEMS WITHIN THE CORE COMPETENCE CONSTRUCTION PROCESS OF CHINA'S SMALL AND MEDIUM-SIZED COMMERCIAL BANKS}

In recent years, as the state has increased its support towards small and medium-sized banks, small and mediumsized commercial banks have undergone rapid development. However, the competence of small and medium-sized commercial banks compared with state-owned commercial banks is still relatively weak, and many problems still exist during the development process.

\section{A. China's regimen regarding small and medium-sized enterprises is imperfect}

Small and medium-sized commercial banks also belong to the category of small and medium-sized enterprises; the cultivation of their core competency need to be realized in the larger environment, including both the outside environment where the enterprises exist and the banks' own environment. The main obstacle to the development of Chinese small and medium-sized commercial banks is a standard and optimal management system of modern enterprises. In order to administer these banks through international standards and advanced world-class management philosophies, constant improvements need to be made to the management system of modern enterprises [2]. As the traditional planned-economy way of thinking has not yet been eradicated, the present management system is hindering the innovative development of China's small and medium-sized commercial banks. The irrational corporate governance structure and capital structure, as well as ambiguous equity responsibilities, are common issues of enterprises in China [3].

\section{B. Lack of knowledge accumulation and innovation of product services}

Seeing from another perspective, core competency is actually a comprehensive kind of competency composed of all kinds of knowledge. In the age of Knowledge Economics, those that succeed in the competitive environment are enterprises that can master the core technology and service level of the industry. Many small and medium-sized commercial banks often focus on imitating the operations of large banks and lack the recognition of the importance of knowledge.

\section{Small and medium-sized banks are short-sighted in terms of strategic vision}

Strategic management is the highest level of management in small and medium-sized commercial banks; it determines the future development state and development strategy of the entire enterprise, while the administrator determines the skill level of strategic management. Currently China's banking industry has not fully opened up [4]. Administrative departments have been assigned administrative personnel from the bank and there are few managing personnel with an international perspective. Presently, the management level lacks foresight into the development strategy of the market situation; it has not yet fully utilized its advantages towards the construction of a core competency. 


\section{Superior resources have not been centralized}

Small and medium-sized commercial banks should gradually construct a core competency and a competitive edge from their own advantages, and avoid being caught in the vicious cycle of cutthroat competition pursuing operations that are identical to superior banks in the industry; only by centralizing superior resources can banks maintain a relatively high competency in the long-term competition.

\section{THE CORE COMPETENCY CONSTRUCTION METHOD OF SMALL AND MEDIUM-SIZED COMMERCIAL BANKS}

\section{A. Construct core values that correspond to characteristics of the bank}

Every successful enterprise has their own set of unique core values; the construction of core values can conduct employees' actions and stimulate employees' creativity, thereby making the improvement of the service level and operation efficiency of the bank more effective [5]. The values and business philosophy of the bank changes along with the change of environment, and during the change gradually forms the culture of the enterprise. A unique enterprise culture reflects the bank's core competency.

\section{B. Obtain product innovation skills}

Innovation is the soul of any type of industry; it is the key to core competency. Small and medium-sized commercial banks should carefully study the characteristics of their client base such as income, consumption and financial management, then combine the banks' own advantages to design and develop new financial service products that satisfy the client base, using the market as guidance, in order to obtain the clients' approval and trust towards the products. Small and medium-sized commercial banks must extensively increase their capital investment in innovations, and improve their strength step by step.

\section{Train managing members of the bank}

Having high quality leaders can greatly influence the development of the bank; their decisions directly affect the bank's success or failure. In order to improve core competency, enterprises should apply different management methods and management systems to restrict actions of the management level, train and improve their leadership qualities and expand strategic vision [6]. Managing members should implement a series of measures to improve their awareness of risk and evasion, innovation encouragement, development of abilities, comprehensive foresight and control of the market, so that they may recognize the bank's own core competency in the intense and versatile competitive environment, and allow the bank to quickly develop and continuously improve itself.

\section{Strengthen the management of human resources of the bank}

Human resource is the motive force for modern banks to strengthen their own abilities. The proper use of human resources is the key to improving a bank's service level and business efficiency; being the main resource of the bank, it plays an important and irreplaceable role in the construction of the bank's core competency. Banks should increase the training and guidance of employees, further improve the skill level of employees, build the human resources of the bank into a strong intellectual resource, stimulate with the highest strength the creativity and enthusiasm of employees, and improve the management system of human resources in order to create a strong safeguard for the establishment of the core competency.

\section{CONCLUSION}

Presently, and for a while into the future, there will be continuous depression in the international economy, with deleveraging and the sovereign debt crisis difficult to recover from. China's economic development will gradually transform towards the endogenous economic growth model, deeply advancing towards marketing and commercialization reform, accelerating the interest rate reform, as well as constructing and implementing the counter-cyclical macro-prudential regulatory framework. In the new economic and financial situation and trend, China's small and medium-sized commercial banks need to work hard and advance forward continuously. The question of small and medium-sized commercial banks practicing market positioning in overall national strategic framework and realize their transformative development has become a significant theoretical and practical proposition [7]. As reflections upon this question are still in preliminary stages, this article has analyzed the current development status of China's small and medium-sized commercial banks, discussed problems that emerged during the construction process of small and medium-sized commercial banks' core competency, and suggested construction methods of the core competency of small and medium-sized commercial banks. Establishment of the core competency can prompt the overall reform of the small and medium-sized commercial bank industry, and explore as well as achieve step-by-step the transformation and development of China's small and medium commercial banks in midst of competition.

\section{REFERENCES}

[1] Wei, Lu, A nationwide analysis of the core competency of commercial banks, vol. 7. CO-Operative Economy \& Science, 2016, pp. 32-34.

[2] Sun, Zongkuan, "A study of the development strategy of China's small and medium-sized commercial banks," Beijing: China Financial Publishing House, 2015, pp. 100-120.

[3] Zheng, Wenrui, Qiu Xia and Guiping Luo, The method of improving the core competency of commercial banks, vol. 9. Finance \& Economy, 2013, pp. 88.

[4] Dong, Shaoqing and Jiangang Xia. Exploration and analysis of methods of core competency improvement in China's commercial banks, vol. 21. Commercial Times, 2013, pp. 78-79.

[5] Long, Jianguo and Lin Long. Strategy of improving core competency in small and medium joint-equity commercial banks, vol. 24. COOperative Economy \& Science, 2013, pp. 58-60.

[6] Yang, Chao, Methods of improving core competency in small and medium-sized commercial banks, vol. 9. Management \& Technology of SME, 2014, pp. 5-6.

[7] Li, Zhenxi, "A study of the core competency of small and medium-sized commercial banks," Beijing: China Financial Publishing House, 2007, pp. $60-82$. 